Fall 2016

(Revised in February 2017)

\title{
The Marxist Explanations for Financialization: A Critical Review
}

\author{
Baris Guven
}

\section{Introduction}

The paper provides a critical review of the main Marxist explanations for financialization of the US economy. It also contributes to the Marxist literature by emphasizing the link between neoliberalism and financialization, and flexible accumulation and financialization. Specifically, we argue that investment bankers played a leading role in initiating the constitution of neoliberalism in the face of the geographical reorientation of the industrial capital, and that the shareholder principle that came to dominate the corporate governance has led to the changes in the organizational and employment structure of big corporations contributing to the formation of flexible labor market structure.

The operative definition of the concept financialization for the whole paper is "the increasing role of financial motives, financial markets, financial actors and financial institutions in the operation of domestic and international economies" (Epstein 2015). As 
Fall 2016

Epstein notes, this definition lacks specificity but incorporates many features of financialization process. This is appropriate for our purposes because it allows us to treat a set of different accounts in this work. As the reader will see, however, each Marxian account offers a distinct view of financialization: each defines it in its own way highlighting different elements of a broader process and offering a different explanation for its coming into existence, and financialization vis-à-vis neoliberalism is interpreted differently. We view financialization as a powerful dynamic centered on financial activities and profits in governing capital accumulation process under the flexible regime of accumulation, which has been overall governed by the neoliberal mode of regulation. It encapsulates a range of sub-dynamics and puts its mark on almost every aspect of capital accumulation with the significant consequences for the reproduction of society.

The plan of the paper is as follows. Six different Marxist explanations for financialization are reviewed respectively. For those that build on a theoretical framework, the framework is analyzed first and followed by the analysis of financialization. The conclusion part presents our own arguments on the particular aspects of financialization.

\section{Six Marxist Accounts of Financialization}

\subsection{Financialization in Monopoly Capital School: The Triumph of Financial Capital}

The underlying model of capitalism postulated in Monopoly Capital took the oligopolies given as the fundamental units of the US capitalism starting from the late $19^{\text {th }}$ century (Baran and Sweezy 1966). Even though the markets were dominated by oligopolies, the pricing behavior made the markets work as monopoly markets. The most competitive/successful firm set the price and the other players in the market took the 
price as given (co-respective pricing). The combination of this pricing behavior with the technological change that reduced the labor cost created more and more surplus. Baran and Sweezy argued even that Marx's formulation of the falling rate of profit due to rising organic composition of capital was articulated, and hence valid only, for the competitive capitalism in Britain. In monopoly capitalism, on the contrary, both the rise of the absolute amount of surplus and its share in the national income were the case. Nonetheless, this monopoly capitalism was a contradictory totality. The very same features of monopoly capitalism brought about the barriers to the reinvestment of surplus. While the structures of monopoly capitalism were producing the ever-increasing surplus, there were not enough investment outlets to absorb the surplus. Since the surplus that would not be absorbed will not be produced, monopoly capitalism, the mature form of capitalism in action, has an inherent tendency to stagnate. The clearest sign of this stagnation tendency was the declining investment and the increasing unemployment. The stagnation was the normal whereas the expansion was the exception. However, monopoly capitalism experienced remarkable expansion periods. How were these expansion periods could be reconciled with the model's suggestion? The only way in which this tendency could be pass over was the emergence of epoch-making innovations (railroad, automobile, electronics?). Moreover, each epoch-making innovation was the driving force that helps the system suppress the stagnation tendency within each expansion period. As far as the post-war expansion or boom is considered, the impact of the war on the economy defined by monopolies was decisive. Several factors related to the Second World War that fueled the incentive to invest in the post-war period were the following:

(1) the need to make good wartime damage; (2) the existence of a vast potential demand for goods and services the production of which hand been eliminated or 
greatly reduced during the war (houses, automobiles, appliances, etc.); a huge pool of purchasing power accumulated during the war by firms and individuals which could be used to transform potential demand into effective demand; (3) the establishment of U.S. global hegemony as a result of the war: the U.S. dollar became the basis of the international monetary system, prewar trade and currency blocs were dismantled, and the conditions for relatively free capital movements were created - all of which served fuel an enormous expansion of international trade; (4) civilian spinoffs from military technology, especially electronics and jet planes; and (5) the building up by the United States of huge peacetime armaments industry, spurred on by major regional wars in Korea and Indochina (Sweezy 1982, 7).

Nonetheless, all these factors that contributed to the post-war boom died out and the stagnation was prevented with increasing national and international debt creation, frantic speculation and inflation. Stagnation once again came back in the 1970 s as it did in the 1930s, and Sweezy was pessimistic about the prospect for the economy:

... no one can say for sure that there will never be other powerful stimuli to investment, such, for example, as were provided by the industrial revolution, the railroad, and the automobile in earlier times. What one can say, I think, is that nothing like that is visible on the horizon now (8).

Looking back from the mid-1990s, Sweezy argued that a new stimulus came to the rescue of capitalism in stagnancy. This new stimulus took the form of a 'relatively independent' financial superstructure "sitting on the top of the world economy and of its national units" and consisting of "banks -central, regional, and local- and a host of dealers in a bewildering variety of financial assets and services" (Sweezy 1994, 5). ${ }^{1}$ It is important here to note that the relationship between financial capital and real productive capital changed in the sense that, in the contrast to the previous subordinate role of financial to productive capital through which the former financed the accumulation of the latter and expansion of the former relied on the expansion of the latter, starting from mid-

\footnotetext{
${ }^{1}$ FIRE (finance, insurance and real estate) was just another surplus-absorbing outlet that would countervail the stagnation tendency (Baran and Sweezy 1966). Irrespective of the central argument of Monopoly Capital, the rising scale of this triad in neoliberalism has to be addressed in any account.
} 
1970s the latter emerged as the avenue where the stagnancy-ridden real capital started flowing into (5-6). Sweezy pointed out also that the turn included the configuration of power of financial capital vis-à-vis productive capital and the holders of political power. The decisions of the multinational oligopolies and the policies of governments were increasingly shaped ("constrained and controlled") by "financial capital as it operates through the global network of financial markets" (6-7). Notably, this argument modifies Hilferding's analysis of finance capital.

This analysis is supported by a later representative of the School. Foster (2007) calls to the rise of new capital monopoly-finance capital "in which financialization has become a permanent structural necessity of the stagnation-prone economy". Relatedly, he also underlies the argument previously made by Sweezy and Magdoff that the expansion of financial activities did not undermine the growth but help the economy to suppress the stagnation (4). Notwithstanding the emergence of financialization and its functionality for growth, the average growth was modest compared to immediate post-war period and periodically bursting bigger bubbles. Interestingly, Foster and Magdoff (2008) ascribes the problem to the declining share of wages and salaries in the national income which was the result of the "accelerated class war against workers to raise profits" as a response to the stagnation in the 1970s (17; emphasis added). ${ }^{2}$ As a result, not only the household debt but also the debt of both financial and non-financial firms with respect to GDP skyrocketed in the last three decades through financial explosion "as capital sought "leverage" its way out of the [stagnation] problem by expanding debt and gaining speculative profits" (9). Moreover, in contradiction to earlier argument made in Foster

\footnotetext{
${ }^{2}$ This is interesting because Monopoly Capital (1966) notoriously underestimates the role of the struggles by workers over wages and labor process. It was argued that since the giant enterprises set the price with a mark-up over the labor costs, the wages cannot pose a threat to the profits.
} 
(2007) in terms of the functionality of financialization in overcoming stagnation tendency, the increasing flow of surplus to financial instruments via institutional investors and the lack of enough demand brought the long-run decline of the capacity utilization rate and the divergence of profit rate from the net capital formation in manufacturing industry (19-21). ${ }^{3}$ The authors rather easily conclude that this dynamic represented a shift from the M-C-M' circuit to M-M' circuit "in which money simply begets more money with no relation to production" (21). ${ }^{4}$

Last but not least is the suggested nexus between financialization and neoliberalism. Neoliberalism is seen by Foster as the "ideological counterpart of monopoly-finance capital" similar to the role of Keynesianism in the monopoly capital stage. Particularly, financial globalization imposed the liberation of certain areas such as capital flows and the rate of interest as suggested by neoliberal economic ideology (Foster 2007, 9-10). Thus he assigns to financialization the role of the main driving force of the economy while relegating neoliberalism to the ideological domain so as to function to remove barriers before financialization.

\subsection{Financialization in Social Structures of Accumulation (SSA) Theory: Byproduct}

\section{of Neoliberalism}

Social structure of accumulation refers to the coherent and long-lasting set of institutions (behavioral patterns) that promote capital accumulation and profit-making. SSA is the institutional framework within which the decisive agents of capitalism take their decisions and operate, and hence it regulates the economic activity (Kotz and Wolfson

\footnotetext{
${ }^{3}$ Foster (2010) revises the functionality of financial explosion for growth argument more clearly by saying that "[f]inancialization was unable to alter the underlying problem of stagnation within production, and in some ways, even aggravated it".

${ }^{4}$ We will see below how this 'puzzle' will be solved by the explanations provided by other Marxist strands.
} 
2010). ${ }^{5}$ The capital-labor relation is the main component of each SSA and dominates the main contours of SSA and accumulation. ${ }^{6}$ The financial system, it is fair to say that, has been paid less attention in the SSA theory. A relatively late attempt that explores the role of the financial system in SSA is made by Wolfson (1994). Wolfson argues that the financial system of postwar SSA (or regulated SSA) emerged from the financial turmoil of the 1930s as the structural characteristics of the previous financial system and the relationships of class forces fused to engender the emergence of the new financial system. The low level of private debt and low inflation during the Great Depression years made possible the low and stable interest rates in the postwar SSA. More importantly, the response to the financial turmoil was the legislation of a series of acts: the Banking Act of 1933, the Securities and Exchange Act of 1934 and the Banking Act of 1935. The changes introduced were decisive and included "the separation of commercial and investment banking; the prohibition of the payment of interest on demand deposits and ceiling interest rates on time deposits; the creation of the Federal Deposit Corporation, the Federal Home Loan Bank Board, and the Securities and Exchange Commission, and perhaps the most significant change, the introduction of federal insurance of deposits" (134). ${ }^{7}$ The new domestic financial system reduced the excess competition among financial capitalists/institutions and the abandonment of laissez faire by the government to regulate the system. On the international side, the establishment of the Bretton Woods System in 1944 under US hegemony solved the international liquidity problem assigning

\footnotetext{
${ }^{5}$ For the early formulations and the evolution of the notion of SSA, see Gordon et al. (1994) and Bowles et al. (1990).

${ }^{6}$ Notwithstanding the similarities between the SSA theory and the Parisian Régulation Approach (PRA) as regards institutional analysis, SSA theory does not have a similar notion of regime of accumulation of the PRA.

${ }^{7}$ Financial speculation and failures of a large number of banks created an alliance among labor and popular movements, business interests, and small banks, which was decisive in the passage of federal deposit insurance (137).
} 
to dollar the reserve currency role and created a system of fixed exchange rates (138-9). The new configuration of the domestic and international financial system was the integral part of the regulated SSA, and it served to promote stability, enhance profitability, and moderate class conflict (137-9).

Each SSA, after fulfilling its function to support accumulation and profit-making, is followed by a crisis period in which existing institutions of SSA cannot serve to promote accumulation and, in fact, blocks it. ${ }^{8}$ Put simply, it has been argued that success breeds failure. Similarly, Wolfson argues that capital accumulation in the postwar period “... resulted in changes in the initial conditions - the structural characteristics of the financial system and the relationship of class forces- upon which the institutional structure of the financial system had been built. Under changed conditions the institutional arrangements that had supported growth in the early postwar period now become obstacles to further successful capital accumulation." (139). ${ }^{9}$ The collapse of fixed exchange rates of Bretton Woods System followed the dollar glut in the international financial market as the Western European and Japanese corporations outperformance in competition over American corporations brought about the increasing balance-of-payments deficit. The Vietnam War led to the overheating of the economy creating inflationary pressures in the domestic economy. In addition, increasing financial fragility turned into financial instability due to the upsurge in the bank loan loss ratio and rising interest-gross profit ratio in the business sector starting from the late 1960 s and continuing to 1980 s (139-

\footnotetext{
${ }^{8}$ Here we do not intend to say SSA theory is a functionalist theory. Nonetheless, it is a matter of interpretation how to see the relationship between constituent institutions of SSA and capital accumulation.

${ }^{9}$ It should be noted here that what makes the existing SSA unsuitable is the problems emerging in capital accumulation. However, SSA theory, as it is noted above, lacks a notion to conceptualize the noninstitutional features of capital accumulation. The theory only suggests that the dynamics of capital accumulation shaped and regulated by SSA changes as SSA changes.
} 
141). The turbulence in the financial system and technological progress produced a set of changes:

Inflation combined with increasing debt and financial fragility (and also Federal Reserve tight monetary policy in the early 1980s) to raise the level of interest rates. Higher and more volatile interest rates destroyed the viability of interest rate ceilings and led to disintermediation, especially of thrift institutions [savings and loan associations]. Technological change, by dramatically increasing the ability to move money electronically, contributed to the financial innovation of money market mutual funds, led to disintermediation on a massive scale, and helped to break down the walls among financial institutions created by "compartmentalization." ... The development of the Eurodollar market and the globalization of finance in the 1960s and 1970s led to opportunities for expansion and growth of US multinational banks... Globalization also resulted in increasing competition from the expanding role in the United States of branches and agencies of foreign banks. Increased competition was further heightened by technological change and financial innovation, which enabled nonbank financial institutions to challenge areas of banking formerly the province of banks and thrifts (140).

Writing back in 1994, Wolfson was not sure on whether the efforts to deregulate the financial system was a new financial component of a new SSA (142). Nonetheless, he noted that what was changed in the financial system (the collapse of the Bretton Woods system, increasing financial fragility and volatility of interest rate following the deregulation efforts) did not contribute to rapid accumulation (141). ${ }^{10}$

The full recognition of financialization in the SSA tradition appeared in the works of David Kotz (Kotz 2011; Kotz 2015). ${ }^{11}$ There are two important points in his works that need to be emphasized; one regarding the relationship between financialization and neoliberalism and other regarding what financialization is about. We will take up the first in the next section and the second in the conclusion part.

\footnotetext{
${ }^{10}$ Wolfson, following the Minskian tradition, pointed out also the fragility-increasing role of government protection of the financial institutions.

${ }^{11}$ The first work was initially written in 2008 .
} 
Fall 2016

\subsection{Duménil and Lévy on Financialization: Counter-Offensive of Financial Capital}

Duménil and Lévy's analysis of financialization starts from the capital profitability and focuses on the distribution of profits among the fractions of dominant classes. In the introduction of Duménil and Levy (2004), they define finance in its direct relationship to neoliberalism:

... neoliberalism is the expression of the desire of a class of capitalist owners and the institutions in which their power is concentrated, which we collectively call "finance," to restore -in the context of a general decline in popular struggles- the class revenues and power, which had diminished since the Great Depression and World War II (2).

During the profitability crisis of the 1970s, the revenues of ruling classes eroded and the initiative to fix this erosion came from the center of the center, which is "made up of a particular fraction of the dominating classes" with preponderant financial interests. This finance fraction was "the great instigator of the transition to neoliberalism, and was its great beneficiary" (9). Nonetheless, what was initially crucial for the rising power of finance was their reaction to the soaring inflation in the 1970s. The continuous rise in the price level meant the loss in the real value of the money capital lent by the financial institutions as it was transferred to nonfinancial companies. Finance's response to this erosion was to force the central bank in the US to raise interest rates. Following the interest rate spike in 1979 ("the 1979 coup"), the real interest rate on the long-term credits jumped from its negative values in mid-1970s to high positive values for the 1980s and 1990s picking at almost 9 percent in early 1980s (69-70). This interest rate spike led to a set of distributional shifts in the economy. Before going into detail of these, however, it is necessary to stress the problematic nature of the nexus between the rise of finance and neoliberalism in Duménil and Lévy's account. As it is implied in the quote 
above, they argue that neoliberalism is the reconfiguration of distributional dynamics in favor of a class of capitalist owners and the institutions (i.e., finance). ${ }^{12}$ Moreover, they also argue that what was aimed by the interest rate hike was to reverse the process of the deterioration of revenues of this same class. Also, they rather easily suggest, without providing a substantial and convincing explanation, that " $[t]$ he decrease in profit rates in the 1970s led first of all to a surge of inflation" (77). Then it appears that neoliberalism came into existence as the finance acted starting from the late 1970s to obtain its hegemonic position vis-à-vis the owners of the productive capital. However, there is no reason to argue, in what is presented in Duménil and Lévy's account, that the capitalist owners with preponderant financial interests were the protagonists of the transition from the immediate postwar institutional configuration (say Fordism) to neoliberalism. If the institutionalization of the attack of capital on labor would be a constitutive element of neoliberalism, which must be, what are the casual links between the rise of finance and the new institutional features regarding labor, i.e., stagnant wages, flexibility, casualization of work, decline of unionization etc. ${ }^{13}$ Relatedly, there is no reason to reduce neoliberalism to the effects of what finance has done. As it is aptly argued by Kotz (2015), the former refers to a broader set of institutional features including the relationship between capital and labor, capital and capital, the role of state regulation in

\footnotetext{
${ }^{12}$ Nonetheless, it could be said that in the analysis of Duménil and Lévy the casual links between neoliberalism and financialization is not only problematic but also ambiguous. For instance, they state "neoliberalism [in the US] has simultaneously freed finance from financing company investment and favored households' and the state's negative savings..." that suggest that the former brought about the latter (125). See also Chapter 15 (128-139) suggesting such an interpretation.

${ }^{13}$ The decline in the rate of accumulation as finance has appropriated more of the surplus value causing higher unemployment rates in neoliberalism, as argued by Duménil and Levy, of course, contributed to stagnant wages. However, it was not the only reason that led to stagnant wages. Even high level of employment in the US economy in the 1990s did not produce increasing real wages. The capital-labor relation was modified dramatically by the big capital, and the systemic unemployment, though it helped, was not the only reason behind stagnant wages. Moreover, a set of important changes including worsening of work conditions and shorter job tenure were manifest in the labor markets.
} 
economic activity, and ideology. He also provides a good evidence that the big corporations in US economy gradually withdrew their support in the 1970s for the regulation of the economic activity as the capital accumulation process run into difficulties as the rising bargaining power of labor, increasing international competition and the state's regulative intervention concerning environmental and consumer protection had started to devastate capital profitability. ${ }^{14}$

Assigning the interest rate spike in 1979 a decisive role, Duménil and Lévy argue and show empirically that the rise in the real interest rate led, in US and France, to siphoning of surplus value created in non-financial corporations by financial institutions, increased public deficits, upsurge in household debt (with the contribution of wage stagnation), the American banking crisis (of banks, and savings and loan associations), and the burst of Third World debt crisis in 1982. The globalization of markets and the international capital mobility, as financial mechanisms have become autonomous with respect to production, brought about financial crises in Mexico (1994), Korea (1997), Brazil (1998), Turkey (1999) and Argentina (2001). They also argue that the appropriation of a significant part of surplus value by finance as the net interest from the non-financial corporations, which was not the case before mid-1970s, slowed down the rate of accumulation (growth) as it was determined by the lower rate retained profits of the later (especially in France). Additionally, non-financial corporations have distributed a sharply risen share of profits as dividends (most spectacularly in US) (69-118). The non-financial companies have continued to rely on gross retained profits to finance their investment

\footnotetext{
${ }^{14}$ See also Kotz (2011) for a detailed critic of the role of finance in the emergence of neoliberalism in Duménil and Levy (2004). Nonetheless, in the last part of this paper, we will highlight, among others, a local but telling event that took place in NYC in mid-1970s to suggest a stronger link than suggested in Kotz $(2011,2015)$ between finance and neoliberalism.
} 
and, in fact, reduced their level of net debt ("the flight from borrowing") as a response to the rise in interest rates (120). Moreover, the role of stock market to channel the idle funds to financing of investment remained negligible. In comply with the logic of financialization, corporations issued stocks in order not necessarily to obtain funds for investment but to buy stocks of other corporations (123).

To recap, finance has freed itself from financing real accumulation and started to finance itself (124-5). On the distributional side; non-financial corporations, households and public administrations have paid a large amount of interest to financial corporations. The rate of profit of financial corporations (including capital gains), which remained below that of non-financial corporations for the most part of the postwar period, surpassed the latter in mid-1980s both in France and US, and rose sharply thereafter (134). Starting from the mid-1970s the ratio of financial gains (interest payments, dividends and gains from increases in the stock market) to the disposable income showed an upsurge, more sharply in the US (136). All assets (real plus financial assets minus debt) possessed by the richest 1 percent in US remained high at 30 to 35 percent between 1950s and 1970s. During the profitability crisis with an upsurge in inflation, this ratio dropped to 22 percent. However, it rose to 35 percent in 1986 and kept rising at lower speed until 1998 (138). Citing Edward Wolff's work on the income distribution, Duménil and Lévy also state that "[i]n 1983, 22 percent of rich families, ... declared that they worked in ... finance, insurance, and real estate...; by 1992, this rate reached to 36 percent" (ibid.). A similar process took place in France, owning securities playing an important role in the deterioration of the income distribution. ${ }^{15}$

\footnotetext{
${ }^{15}$ They mention "the neoliberal turn" in this context and their analysis attributes this distributional shift mostly to rise of finance that fed on neoliberalism (ibid., Chapter 15). See also footnote 10.
} 
Fall 2016

\subsection{Financialization in World System Perspective: Recurring Stage of Accumulation after Rising Inter-Capitalist Competition}

The ambitious study of the last five centuries of capitalism (capitalist world-economy) by Arrighi is another attempt to understand the financialization era of the last four decades (Arrighi 2010). This analysis differs from the other Marxian accounts of financialization in at least two respects: a) financialization is put in a very long-term perspective, b) it goes beyond the economic realm by incorporating the political realm (state power, interstate competition, hegemony, etc.) into the analysis.

The conceptual apparatus of The Long Twentieth Century is a composite one in the sense that many concepts and frameworks originated in the different (mostly Marxian) approaches has been flexibly utilized in his analysis. For instance, the regime of accumulation of the PRA is utilized not to refer to a comparatively short period of regularized mode of accumulation but to refer to a longer period of time of accumulation pattern differently realized under different hegemonic states of the capitalist worldeconomy. Similarly, the M-C-M' circuit of capital is referred to as the systemic cycle of accumulation consisting of the sub-cycles of $\mathrm{M}-\mathrm{C}$ and $\mathrm{C}-\mathrm{M}^{\prime}$, where the former is the phase of material expansion describing the continuous change of the world-economy growing along the single development path, and the second is the phase of financial expansion in which the radical restructurings towards another path of the world-economy take place (9).

For the purposes of this paper, we will focus on the part on the latest era of financialization, i.e., post-1970s, in the intractably rich analysis of Arrighi (277-335). He designates the period from the late $19^{\text {th }}$ century to the early $21^{\text {th }}$ century as the US 
systemic cycle of accumulation. The crucial innovation in the world-economy in the late $19^{\text {th }}$ century was the formation of vertically integrated, bureaucratically managed multiunit US enterprises as a response to the tough market competition. These enterprises were the key constituent elements of the prospective US regime of accumulation (the material expansion phase of its systemic cycle of accumulation) and enabled, with the contribution of geographical/territorial (the location of the US vis-à-vis the Western-Europe) and political (state support) factors, the US economy to attain its competitive edge over the small- and medium-scale flexibly specialized British enterprises. The full-fledged blossoming of the US regime of accumulation waited till the end of Second World War. The dissolution of British systemic cycle of accumulation and the success of the US enterprises, all facilitated by the protectionist measures of the US government, had led to the concentration of world liquidity in the US in the period between the two world wars, and this was a serious obstacle to remove to pave the way for the integration of the Western states to the world-economy under the leadership and dominance of the US. It was the contribution of the massive rearmament after and during the Korean War, in addition to the otherwise insufficient the Marshal Plan and the foreign direct investment in the Europe by the US corporations, that solved the liquidity problem the result being the European integration and world economic expansion. This was the so-called Golden Age of capitalism:

$\ldots$ the 1950s and 1960s, like the 1850s and 1860s, constitute another (MC) phase of material expansion of the capitalist world-economy- a period, that is, during which surplus capital was thrown back into commodity trade and production on a sufficiently massive scale to create the conditions of renewed cooperation and division of labor within and among the separate governmental and business organizations of the capitalist world-economy. To be sure, the speed, scale and scope of the conversion of surplus capital into commodities were greater in the US cycle than in any previous cycle [the Genoese, Dutch, and British cycles]. 
Nevertheless, the phase of material expansion of the 1950s and 1960s resembled all the others in one key respect: its very unfolding resulted in a major intensification of competitive pressures on each and every governmental and business organization of the capitalist world-economy and in a massive withdrawal of money capital from trade and production (307; emphasis added).

Arrighi marks the period between 1968 and 1973 as the transition period from the material MC phase to the financial $\mathrm{CM}^{\prime}$ phase of the US cycle. What happened in this period? The intensified inter-capitalist competition put a serious pressure on the prices of primary inputs. The real wages rose much faster than labor productivity in both North America and Western Europe between 1968 and 1973. In addition, even before the 1974 oil shock (three-fold price increase), the price of crude oil imported by OECD countries doubled between 1970 and 1973. Therefore, there was a profitability crisis (or the signal crisis of the US systemic cycle of accumulation) (323) due to the "overaccumulation of capital in relation to the inelastic supply of both the laboring population and primary products" (314-5). It was with the beginning of this crisis of profitability that the financial expansion started as the most important players of the New York money market and Eurodollar market, i.e., the US multinationals, made their move (310-312):

It began in 1968, when the growth of liquid funds held in the London-centered Eurodollar market experienced a sudden and explosive acceleration. As a result of this explosive growth, by 1971 the US government was forced to abandon the fiction of the gold-dollar exchange standard, and by 1973 the US Federal Reserve and associated central banks had to acknowledge defeat in their struggle to stem the tide of mounting speculation against the regime of fixed exchange rates which had dominated high finance during the phase of material expansion of the 1950s and 1960s (310).

The direct result of the breakdown of the fixed exchange rate system was the massive expansion of foreign exchange trading; by as early as 1979, the volume of foreign exchange trading surpassed that of world trade by more than eleven times $(\$ 17.5$ trillion to $\$ 1.5$ trillion) (308). The increased volatility in the price of the foreign exchanges and 
the ensuing increase in the risk and uncertainty forced corporations to engage in currency trade and speculation providing circular impetus to the financial expansion (320). Moreover, even though the loose monetary policies of the Federal Reserve helped the US multinationals in the face of intensified competition, they accentuated the expansion of the offshore money markets (323). The abundance of private dollar in the Eurocurrency and offshore markets, and the competition among the players of these markets over countries of a range of creditworthiness deteriorated the seignorage privileges of the US government and threatened the dollar itself as a viable world money (324). It was in this setting that the sharp reversal in the US monetary policy took place:

By 1978, the US government was faced with the choice of bringing the confrontation with the cosmopolitan financial community that controlled the Eurocurrency market to a showdown by persisting in its loose monetary policies, or seeking instead accommodation through a stricter adherence to the principles and practice of sound money. In the end, capitalist rationality prevailed. Starting in the last year of the Carter presidency, and the greater determination under the Reagan presidency, the US government opted for the second line of action. And as a new "memorable alliance" between the power of state and capital was forged, the looseness of US monetary policies that characterized the entire Cold War era gave way to an unprecedented tightness (324-5).

Moreover, Arrighi views both the tightening of US money supply and four other measures (the interest rate hike, the deregulation of banking in the US, the spike in the state indebtedness, and finally the escalation of the military spending) as conscious efforts to recentralize the privately controlled money in the US not only to restore the confidence in dollar but to restore its hegemonic power (326-7). More importantly, he argues that “... the most compelling reason ... was that the US government's pursuit of power by other means [military and ideological] was yielding rapidly decreasing returns" in the face of the crisis of US world hegemony (330-31). 
To sum up, Arrighi views the financialization phenomenon of the last four decades as a result of the crisis of profitability between 1968 and 1973 of capital in production and trade due to the intensified inter-capitalist competition and the declining hegemonic power of the United States under the configuration of the world-economy by the US regime of accumulation. The migration of capital facing 'diminishing returns' in production and trade from these realms to financial transactions gave rise to the collapse of the fixed exchange regime. This, in turn, led to the explosion in the foreign exchange trading pushing up the every economic agent to take into consideration the rising risk and uncertainty and do more financial transactions. The efforts of the US government to restore the declining hegemony brought about its marriage with private finance and the concentration of private mobile capital in the US. Concomitantly the social polarization in US became sharper as it was observed in the financial expansion phases of the all previous systemic cycles of accumulation (325-6).

\subsection{Financialization in the Parisian Régulation Approach (PRA): Financial System}

\section{Replaces Fordist Wage Compromise in the Regulation of the New Growth Regime}

The PRA has been an influential research agenda to study the evolution of capitalism. Developed in the crisis-ridden 1970s and 1980s by scholars such as Aglietta, Lipietz, and Boyer the PRA endeavored to analyze capitalism both in its expansion and crisis periods. In a nutshell, the underlying premise of the approach is that the conflictual social relations of capitalist production pose barriers to successful accumulation of capital, and hence these conflictual relations have to be regulated/normalized within/through a set of structural forms or institutions in and through which accumulation of capital takes place until the new barriers emerge. Thus, as a set of institutions, or a mode of regulation 
Fall 2016

(MoR), comes into existence, a corresponding regime of accumulation (RoA) is established. In fact, the constitution of both MoR and RoA is reflexive as they are established in interaction not isolation. The reflexive constitution of these gives rise to the formation of the certain tendencies in the institutionalized capital accumulation process, and the latter, in turn, bring about serious barriers to accumulation itself, hence crises, such that their resolution requires an institutional fix, i.e., a new mode of regulation so that a new and functioning accumulation regime could be established (Aglietta 1979; Boyer 1987; Jessop 1990; Jessop 2013a; Lipietz 1987; Lipietz 1993; Lipietz and Vale 1988).

The most widely circulated notion of the PRA has been Fordism, which refers to the mode of development (the articulation of MoR and RoA) of capitalism between 1945 and 1973. The analysis of the rise and fall of Fordism influenced many social scientists and, the approach has been adopted in many areas of critical studies. However, as far as the political economy is considered, the PRA lost its previous influence and never produced an analysis of post-1973 capitalism as complex and comprehensive as that of Fordism. Consequently, the analysis of financialization by the PRA remained narrowly focused on certain institutional aspects of the dominance of finance though they are quite important for an adequate understanding of the accumulation patterns in financialization.

In essence, the PRA argues that the liberalized financial system or financial liberalization is the most important element of the new mode of regulation in the post1973 period replacing the equally indispensable Fordist wage compromise of the postwar Fordism. The corresponding new growth regime or regime of accumulation (so-called new economy) became finance-led ( Boyer 2000; Aglietta and Breton 2001; cf. Jessop 
2013). Besides, the interrelations between financial system and corporate decisions have changed dramatically, and the impact of the former on the latter has become more pronounced.

The two major novelties in the financial system were: a) the innovation in the assessment of risk and pricing of assets, and the increased liquidity of securities markets, all backed by the information technology (IT) revolution; b) the rise to the dominance of a new type of financing where the equity markets are the key. Regarding the first one, the effect of the IT revolution has been decisive:

Prior to the IT revolution, relatively few assets were marketized because the conditions necessary to apply the statistical methodology of evaluation were not met for a large range of private debts. But, in finding ways of unbundling complex risks into elements to which theoretical probability distributions could be assigned, computer-assisted financial engineering has drastically enlarged the market logic of pricing [the public opinion of financial markets]. As a result, groups of securities linked to derivatives have blossomed and are traded daily, mainly on over-the-counter markets. The diversity of risk characteristics has been repackaged into a one-dimensional structure of spreads above conventional benchmark prices (Aglietta and Breton 2001, 436-7).

Gained such a technological impetus, a novel type of financial intermediation provided by the financial markets through asset portfolio diversification triumphed the financial intermediation of banks (hence bank-based finance vs. market-led finance). Upon such a classification, Aglietta and Breton distinguishes three types of controlling by finance of corporate sector that directly affect the direction of capital accumulation: bank control by debt, direct control of majority shareholders, and stock market control by predators and minority shareholders. Leaving aside first one, the second group aims to maximize the financial return on equity, and third group the maximization of share price. While the second group's demand to appropriate more surplus takes the form of more dividend payments and share buybacks, the threat of take-over by the third group financial players 
forces the corporate managers to promote share prices (443-6). Aglietta and Breton argue that the more dominant these financial actors are, the lower the rate of growth is as the more surplus goes to pay dividends and managers become less forward-looking (455).

Boyer depicts more interrelations between the financial system and the other components of the finance-led growth regime. Thus, in addition to the market-led finance's control over corporate investment decisions, financial system affects the rest of the economy by imposing the credibility over the government decisions and limiting public borrowing, mediating the privatized pensions funds, creating a wealth effect on consumption as the households hold more equities, and accentuating labor contract flexibility under the pressure of shareholder value (Boyer 2000, 118-121).

\subsection{Lapavitsas on Financialization: Financial Expropriation in Neoliberalism}

Another comprehensive analysis of financialization in an empirically rich manner comes from Costas Lapavitsas (Lapavitsas 2013). ${ }^{16} \mathrm{~A}$ set of features of this analysis is particularly important. First, on the nexus between financialization and neoliberalism, similar to what is argued by Kotz, Lapavitsas places the origins of financialization onto the new institutional setting created by neoliberalism. The financial liberalization and the labor market deregulation gave rise to the emergence of the three underlying tendencies of financialization (39). ${ }^{17}$ First, the non-financial enterprises (monopoly capital) have relied less on the bank loans and "have become 'increasingly involved in financial processes on a independent basis, often undertaking financial market transactions on own account..." (5). This tendency was in sharp contrast to that of the analysis of finance

\footnotetext{
${ }^{16}$ For a concise statement of the theoretical approach behind the analysis, see Lapavitsas (2011).

${ }^{17}$ Lapavitsas's empirical analysis covers the US, UK, Germany, and Japan. As it is emphasized in his work, there is no complete uniformity in the patterns of financialization in these countries, reasons being related to their institutional and historical features. Therefore, we will only report his findings in the most general sense without going into the details of the specificities of the cases.
} 
capital done by Hilferding. There is no amalgamation between industrial and financial (i.e., bank) capital, instead they diverged from each other as the share of external funding in financing the capital expenditures declined (229-30). ${ }^{18}$ As the share of bank loans gradually declined, non-financial enterprises have resorted to securities markets to fund their operations (prominently by issuing or obtaining equities). ${ }^{19}$ On the assets side of the aggregate balance sheet, they have relied less on trade credit and consequently become dependent on the financial markets, though there is no strong movement of a particular asset(s) (226-8). Second, the conduct of banks has taken a different shape. As partial mirror image of non-financial enterprises relying more internal funds and resorting to financial markets, banks turned to individual and household income, and focused on transacting in open financial markets (5). Housing loans formed the backbone of the assets of commercial banks. The lending among banks themselves has also risen. Third, the households have turned to financial markets "to facilitate access to vital goods and services, including housing, education, health and transport" (5). As the public provision of these goods and services has been suspended and the wages has remained stagnant under the dictates of neoliberalism, households willy-nilly applied to the financial system (mostly banks) to obtain these necessities. In addition, the savings of households have increasingly transacted by the private firms in the financial system (ibid). Especially in

\footnotetext{
${ }^{18}$ This claim is, to a large extent, in comply with the claim made by Duménil and Lévy on the financing role of financiers in capital accumulation of productive capital.

${ }^{19}$ The financial instability hypothesis articulated by Minsky focuses on the borrowing between the nonfinancial enterprises and banks, and states that the net worth of the former deteriorates as the speculative motive leads them to borrow more and more during the boom period. As it should be clear, in the financialization era, the central relationship of the financial instability hypothesis à la Minsky has had a negligible relevance. The monopolist enterprises had acquired the ability of having massive internal funds, as it had been emphasized in Monopoly Capital by Sweezy and Baran. This ability, as Lapavitsas, and Duménil and Lévy show, has sustained in the neoliberalism. The source of the financial instability has, however, lied elsewhere. However this clear general picture changes when one looks at the debt ratio (debt over total assets) of the largest corporations. Lin (2016) shows that debt-ratios of Fortune 500 non-financial corporations have risen from around 55 percent in 1982 to 67 percent 2005 peaking at above 70 percent in early 1990s.
} 
the US and UK, the housing loans have grown substantially in the financialization era (239).

There are two specifically important consequences of these tendencies that need emphasis. The first relates to the absolute amount of financial profits. As it shown by various writers, the share of financial profits in the total domestic profits has risen (Kotz 2015; Duménil and Levy 2004; Lapavitsas 2013; Foster and Magdoff 2008). The nature of these profits is particularly important for the Marxian economics. The weight of (mostly sophisticated) financial transactions in the contemporary economy appears to cast a doubt on the contested but powerful argument in Marxian tradition about the source of profit either industrial or financial. Indeed, what has been the source of financial profit in the last there decades given the empirical fact that the distance between the banks capital and non-financial enterprises enlarged? Lapavitsas's work distinguishes itself from the rest by clearly showing the various sources of financial profits (138-68). First, his analysis brings to the fore the category of 'profit upon alienation or expropriation' first appeared in Stueart's An Inquiry into the Principles of Political Economy and then taken by Marx (142-3). The source of profit upon expropriation is not the surplus value created in production but the value itself. The massive income transfer during neoliberalism has, therefore, taken place, partly, through the appropriation of household income through various financial channels. In addition, Lapavitsas shows, building on the 'founder's profit' first appeared in Hilferding's Finance Capital, that capital gains registered in the financial markets via transacting the financial assets (bonds and equities) have come ultimately from the current and future surplus value, though the new loanable capital appears as the indirect source of profits in the form of capital gains (159-68). 
Fall 2016

\section{Concluding Remarks: More on Financialization}

One of the common features among the previous Marxian accounts of financialization is that they take a long-run view of it. That is, financialization is situated in the long-run tendencies of capitalism, and is considered to be a different period/stage in the capitalist mode of production (CMP) or a powerful driver of the economic system. Some explanations focus more on the structural properties of the CMP such as those of Monopoly Capital School and Arrighi while others favor class struggle such as those of SSA School and Duménil and Lévy. Nonetheless, as far the link between neoliberalism and financialization is concerned, all accounts ignore a seemingly local but in fact globally telling event that took place in the condensed and turbulent 1970s. The urban/debt crisis of the New York City (NYC) that came to the surface in 1975, we will argue, was a decisive and path-breaking event in the constitution of neoliberalism and financialization. In addition, a careful analysis of the causes of this urban/debt crisis tells more about the equally neglected interrelations among space, profitability, reactions of the lower classes, and the strategies of capitalist actors. We argue that this sheds light on the changing attitude of the banking industry in US during the 1970s. A method that solely focuses on the pattern of financial profits is very likely to miss the significance of this (and similar events) in the 1970s (and 1980s) and the clues that they can give us for a better understanding of the evolution of capitalism. We also highlight the fact the spatial differences regarding the variables of accumulation in the postwar US are so important that they need to be taken into account for their role in the rise of neoliberalism and financialization. 
Fall 2016

\section{Debt-finance-neoliberalism nexus}

The form that the urbanization in US took was of a Keynesian nature in the post war era. The production of urban space was not only governed according to the spatial division of labor but also to the spatial division of consumption under the Keynesian demand management logic which had been the response to the lack of the effective demand from the 1930 s on. "The Keynesian city was shaped as a consumption artifact and its social, economic, and political life organized around the theme of state-backed, debt financed consumption" (Harvey 1989, 37-8). The New York City was a typical Keynesian city and it went trough the similar debt-creation and expenditure acceleration process in an economic landscape with more footloose industrial capital and more mobile financial capital (ibid., 42). The rising costs and expenditures tended to surpass the revenues in the 1960s and the expenditure-revenue gap was already projected in the 1966 (Tabb 1982, 22). The increase in the city's expenditures during the 1960s was 171 percent while it was 135 on average for the whole nation and 158 for the New York State. In 1969, the state and federal aid amounted to the 47 percent of the city's revenues compared to 28 percent in 1959 (ibid.). Consequently, the public debt of the NYC grew massively in the 1960s and early 1970s, reaching \$11 billion in 1974 (Freeman 2016). The tax-exempt municipal bonds, the main assets for borrowing for the city, were being held by the large investment banks occupying the NYC and their share in the bank portfolios jumped from 21.6 percent in 1960 to 50 percent in 1974 (Tabb 1982, 22-3). It was a lucrative business for the banks to invest in these bonds, and indeed, the banking industry, in as late as 1969, was encouraging the cities to borrow more (ibid.). However, as the city's debt piled up, the banks demanded higher interest rates and, in February 1975, Banker Trust did not 
underwrite a new issue of Tax Anticipation Notes, the security the city started to use to borrow by warranting the uncollected taxes. The serious recession hit the US economy in 1973 and the unemployment rate in the NYC rose to 12 percent by 1975 (Freeman 2016). It was in seemingly such an economic setting the banks left the tax-exempt bond market. Being rejected by the banks and in the face of default, the city officials appealed to Washington to ask for federal aid and the answer was no again. The banks and the federal government, it turned out, agreed on a different action to take to solve the city's problem and theirs:

Conservative leaders in Washington, including Secretary of the Treasury William Simon and White House Chief of Staff Donald Rumsfeld, promoted a radical solution to the financial crisis. They aligned themselves with national business leaders [including 'the cardinals of finance'] to pursue a social and political environment conducive to the restoration of robust profitability and ruling-class power after the decade of leftward drift resulting from civil rights struggles and subsequent social movements (Freeman 2016). ${ }^{20}$

The solution suggested was to impose the first austerity in the epicenter of capitalism. To that end, the city authorized the Municipal Assistance Corporation (MAC) whose board was occupied by the unelected members to sell state bonds and which had control over sales and stock transfer taxes of the city to pay its debt. Taking advantage of being the only lender to the city, the MAC exercised its power to make the city pay its debts at the expense of New Yorkers: tens of thousands of workers were laid off, wages were frozen, welfare benefits were cut, the transit fare was raised, and the tuition was imposed at the hitherto free City University of New York (Freeman 2016). ${ }^{21}$

\footnotetext{
${ }^{20}$ The cardinals of finance included David Rockefeller, chairman of Chase Manhattan Bank; Walter Wriston, chairman of First National City Bank; Donald T. Regan, chairman of Merrill Lynch; and William Salomon, managing partner of Salomon (ibid.). Alan Greenspan, then head of President Gerald Ford's Council of Economic Advisers also argued against aiding the city (Philips-Fein 2016).

${ }^{21}$ For a detailed analysis of the implementation of the imposed austerity, see (Tabb 1982, Chapter 3)
} 
Fall 2016

The Emergency Financial Control Board followed the MAC with more power and finally Washington accepted to aid the city by providing seasonal lending in 1975 . Though the debt problem prolonged until mid-1980s, the austerity policies kept being implemented. Almost half a decade before the attack of Ronal Reagan on striking air traffic controllers and that of Margaret Thatcher on British coal miners, through the agency of the state, the capital-labor compromise of the Fordist era was first broken, in the 'public sphere', by the active role of the investment bankers. They did not simply act on the basis of their profit-oriented rationality; they also helped found the new classpower matrix of the coming era. To be sure, the attitude of the big investment banks toward public debt of the NYC was quite different from the one they took toward the Third World countries after 1974 when the petrodollars of the OPEC countries were deposited in them, and this cannot be better represented in the famous remark of Walter Wriston: "countries do not go bankrupt". But equally reasonably cities do not go either. To make more sense of the changing behavior of the investment banks toward investing in the city's debt in the 1970s, we need to delve into the roots of the urban/debt crisis of the NYC.

\section{Accumulation in Spatial Perspective}

Many accounts of neoliberalism and globalization treat the US economy, to the extent they do, as a uniform entity when it confronted serious problems in the 1970s. However, from 1950s on, the US economy was going through what may be called a spatial reconfiguration of accumulation:

Since the 1950s and 1960s there has been a movement of manufacturing firms and population out of the central cities as the corporate drive for profit has led to abandonment of the older industrial areas in the search for cheaper labor, land, 
energy, and taxes. New plants have been built in suburbs, in southern cities, in rural areas, and overseas, influenced by government policy (Tabb 1982, 72).

Suburbanization brought the declining land values and tax yields for central cities. The significant differences of the variables of accumulation between the north and south parts of the US economy drove the migration of capital from northern industrial states to Sunbelt states. More defense spending, farm subsidies and highway expenditures that most likely to stimulate economic growth contributed substantially to the economic expansion in the Sunbelt states. The weak trade union movement in the south meant the docility of workers divided along the race vis-à-vis the unionized north where with the contribution of increasing demand for rights and welfare of the poor and the black liberation movement became a tough place to production and circulation of capital (734). As these factors induced capital to move out of the northern states, the NYC experienced an important shift in its employment structure, which significantly deteriorated its revenues:

Manufacturing employment in New York City reached a peak of $1,073,000$ workers in 1947, and declined 12 percent by 1960. By 1970, a further 121,000 manufacturing jobs had been lost, and by 1977 another 287,000. In 1950, manufacturing jobs had accounted for 30 percent of payroll employment; by 1980 the figure was 15 percent (75).

Given the generous welfare expenditures of the city in the social democratic/liberal postwar environment and the increasing flow of the poor to the city, the suburbanization and the movement of manufacturing capital to the south eroded the city's tax base making necessary the borrowing and increasing debt. Therefore, when the investment banks decided to leave the municipal bond market, they were responding to the underlying structural transformation that the city had been undergoing. They made up the city on their own image by imposing the austerity on it and enforcing it to further 
transformation. This entailed the orientation of the city to tourism, establishment of free trade zones, further incentives to capital, reconfiguration of urban space by the gentrification projects (Tabb 1982; Harvey 2007).

Thus, in the face of the underlying movement of manufacturing capital to favorable locations, and in a social environment the contours of which were drawn by the welfare state founded on the capital-labor compromise, the banking industry acted strategically: it did not only make a rational decision to protect itself but also determined the patterns of future breaking down for the first time the capital-labor compromise and making austerity a viable option for the future ${ }^{22}$. It was the first effort to reassure its power, and the resolution of the city's debt crisis was the harbinger of the new class-matrix of the US capitalism. As it is emphasized by numerous scholars, the risk of default on debt and the austerity cycle was repeated now in world-scale during the Third World debt crisis in the early 1980s and has continued to be a common practice up to the current period.

\section{Financialization and flexible accumulation}

The second point that we would like to emphasize is about the nexus between the financialization (of the US economy) and the constitution of a new regime of accumulation around the unifying principle of flexibility. Harvey (1990) argues that

\footnotetext{
${ }^{22}$ A similar analysis can be applied to the banking deregulation in the early 1980s. Kotz (2015) points out that the banking industry had never been content with the regulation of its activities. Krippner (2005) shows empirically the rise of finance in the US economy and argues that it could be related to the thesis advanced by Arrighi's long-century analysis. In a later work, however, she argues that the push for the elimination of the banking regulation (of Regulation Q ceilings on the interest rate paid on time and savings deposits) came from the eruption of inflation during the late 1960s and 1970s (Krippner 2011). She then argues that the financial profits (mostly interest payments) derived from the expansion of credit in the deregulated financial system and the reorientation of nonfinancial firms to financial assets and markets in the presence of high and volatile interest rates (ibid., 52-5). One can go beyond this kind of explanations by empirically analyzing the difficulties faced by the banks to sustain their profits in the face of less relying of the nonfinancial corporations on the banks to finance their activities. The capacity of the large non-financial corporation to produce large enough internal funds might be one of the reasons for the banks to push for deregulation in addition to the restrictiveness of the postwar regulatory framework in which they used to operate.
} 
capitalism, particularly US capitalism, has gone through a deep transformation from the 1970s onwards. Making use of the PRA, he views the new patterns of accumulation as a new regime of accumulation:

Flexible accumulation ... is marked by a direct confrontation with the rigidities of Fordism. It rests on flexibility with respect to labour processes, labour markets, products, and patterns of consumption. It is characterized by the emergence of entirely new sectors of production, new ways of providing financial services, new markets, and above all, greatly intensified rates of commercial, technological, and organizational innovation (147).

One of the major changes took place in the work regimes and labor contracts. Though Harvey draws a more comprehensive picture of the change, we focus on a particular but significant part of it for our argument on the relationship between financialization and new regime of accumulation. The relatively uniform labor practices in Fordism based on higher job security and longer job tenure have been subjected to a deep transformation in the flexible accumulation. While the share of the employees with full time and permanent status declined, an increasing part of the labor force have become employed under the conditions of less job security, shorter job tenures, and declining fringe benefits. On the organizational side, sub-contracting and outsourcing have spread with their implications for the labor practices. Harvey also argues that the global financial system was completely reorganized and became a coordinating power for flexible accumulation pointing out the increasing influence of the financial system on the industrial capital and the governments (161-8). Particularly, he points out the blurring boundaries between financial and real capital, and the opening of the financial markets to the corporations who started to look more to the financial system to make profits through shifts in the exchange and interest rates instead of doing their own business, the production of goods and services (163). However, in our view, he never persuasively establishes the nexus 
between financialization and flexible accumulation other than pointing out the creation of a set financial instruments and markets that supposedly eased the functioning of flexible accumulation and the massive increase in the mobility of capital in the financial system. To be sure, the accumulation of capital in the financial markets in which the short-term and incomparably (vis-à-vis the case in Fordism) mobile capital operates is well captured by the conception flexible accumulation. But how exactly the financial system affected the transformation in the labor market structure?

To answer this question, we need to consider a set of difficulties faced by the US corporations in the late 1960s and 1970s and a set of institutional changes that took place in the financial structure of the US economy during the 1970s. This requires us to investigate the existing relations between the financial system and corporate governance in the US economy.

\section{From 'retain and reinvest' to 'downsize and distribute'}

Lazonick and O'Sullivan (2000) argue that the corporate strategy in US regarding the utilization of internal funds was modified significantly in the 1980s. Until the 1980s corporate managers retained the profits and reinvested them to expand their corporations (hence 'retain and reinvest'). However this strategy run into serious difficulties in the face of a set of dynamics during the 1970s. First of all, the retain and reinvest strategy brought the excessive centralization of capital: a typical large corporation included too many divisions and too many different types of businesses, a feature that well describes the Fordist rigidity. The massive expansion of the 1960s thus resulted in the poor performance of the corporations in the 1970s (15). Second, the innovative capability of the Japan competitors in many capital and consumer good industries challenged the 
dominance of the US corporations in those markets (ibid.). Moreover, a set of important changes modified the financial landscape in the US economy. In the inflationary 1970s pension funds and insurance companies had difficulties in offering real rates of return to their clients. With the enactment of The Employee Retirement Income Security in 1974 (which was amended in 1978) pension funds and insurance companies started to allocate the substantial amounts of their funds to buy corporate equities (and other risk securities) in lieu of high-grade corporate and government securities (16-7). Similarly, as moneymarket funds offered higher returns to saver than the regulated banks, due to same reason, the US government enacted The Garn-St. Germain Act in 1982 to allow the savings and loan associations to hold 'junk bonds' and other risky new ventures to compete with money-market funds (17). Thus, the troubles in the corporate structure, the tough foreign competition in the markets, and the pressures originated from the high inflation on the pension, insurance, and savings institutions came together to destabilize the old patterns of corporate strategy and create another one. With the contribution of the arguments in favor of the shareholders being the sole discipliner of the corporate managers, suggested by the principal-agent theory in the 1970s, the shareholder value was entrenched as $a$ principle of corporate strategy. This new principle, in turn, has determined the organizational, investment, and employment patterns of the US corporations. The revenues of the corporations have been increasingly allocated to buy back shares and the distributed share of them to shareholders (pay-out ratio) has risen. ${ }^{23}$ Moreover, the top managers the major US corporations, to increase the internal funds to buy back shares

\footnotetext{
${ }^{23}$ When the SEC instituted Rule $10 \mathrm{~b}-18$ of the SEC Act in 1982, companies were able to buy back their shares on the open market within almost full liberty (Lazonick 2014). This article provides the data on the utilization of net income of some of the largest US corporations. For instance, between 2003 and 2012, Exxon Mobil spent $83 \%$ of its net income on share repurchases and dividend payments, IBM 111\%, Procter \& Gamble $116 \%$, Walmart $73 \%$ and General Electric $81 \%$.
} 
and make dividend payments, started to resort to "downsize the corporations they control, with a particular emphasis on the cutting the size of labor forces they employ, in an attempt to increase the return on equity" (hence 'downsize and distribute') (18). Consequently, the number of jobs offering stable employment and good pay has declined:

... Hundreds of thousands of previously stable and well-paid blue-collar jobs that were lost in the recession of 1980-2 were never subsequently restored. Between 1979 and 1983, the number of people employed in the economy as a whole increased by 377,000 or 0.4 percent, while employment in durable goods manufacturing - which supplied most of the well-paid and stable blue-collar jobs, declined by 2,023,000, or 15,9 percent. ... Between 1983-1987, 4.6 million workers lost their jobs, of which 40 percent from manufacturing sector. The elimination of well-paid and stable blue-collar jobs is reflected in the decline of the proportion of the manufacturing labour force unionized from 47.4 percent in 1970 to 27.8 percent 1983 and to 18.2 per cent in 1994 (18-9).

The downsizing not only affected blue-collar workers. In the early 1990s, tens of thousands of white-collar workers (professional, administrative and technical employees) were laid-off. It became a common currency among the major US corporations. "By the early 1990s even US firms known for their no-lay-off commitments - IBM, DEC, Deltahad undergone significant downsizing and lay-offs of blue- and white-collar workers" (19). This dramatic change is reflected in the decrease in the job tenure. The median years of tenure of employed wage and salary workers with their current employer went down from 5.0 to 4.7 years between 1983 and 1998 (21).

\section{Financial Assets, Corporate Debt, and Employment}

Not only the entrenchment of shareholder value as a principle of corporate organization played a role in the deterioration of the employment structure. The availability of the financial profits that can be made through financial circuits and the rising corporate debt put their mark on the employment. Lin (2016) estimates, by drawing his sample from all publicly traded Fortune 500 nonfinancial corporations between 1982 and 2005, that the 
increase in the financial investment led to a significant decline in total employment size (positive effect on managerial, professional, and service workers but more than offsetting negative effect on blue-collar production workers). Similarly, the rise in corporate debtratio and the returns to shareholders brought the decline in total employment (all types of employment) (10). He specifically argues that financial assets acquiring and investment substitutes the investment in production, and the rising debt-ratio (debt to total assets) forces firms to reduce labor costs especially during the downturns in the economy in face of the requirement of debt service payments (6).

What has been said so far on the nexus between financialization and employment has to be qualified. Both Lazonick and O'Sullivan (2000) and Lin (2016) show that the rise of finance has devastatingly affected the employment growth in the US economy. The large corporations have downsized their labor force significantly, production workers paying the highest price. Given that these corporations had been the locus of stable and secure employment until the 1980s, the dramatic shift took place thereafter clearly explains the blossoming of the unstable and unsecure employment conditions. However, this is only a part of the story. The termination of the labor-capital compromise by mainly the efforts of the big capital is the part and parcel of the same process. The power of the organized labor so deeply challenged the accumulation process in the late 1960s and 1970s in the face of the tough foreign competition that the permanent and secure (and full) employment as a social premise had been deserted by the big capital. The organizational shift toward more sub-contracting and outsourcing, and the decline of stable and wellpaid jobs cannot only be explained by the rise of financialization without taking into consideration the changing attitude of big capital toward the then-powerful working class. 
Fall 2016

\section{Financialization: a solution to devaluation risk of fixed capital?}

A distinct argument on the emergence of financialization from the 1980 s on refers to an inherent tendency in capitalism toward financialization. Kotz (2011) argues that financialization is not simply derived from neoliberalism but it has been a tendency within the corporate capitalism in the face of what we call devaluation risk of fixed capital $^{24}$ :

Any fortune that is stuck in the form of an actual productive enterprise is always in danger of eroding due to competition from new products and new processes. Hence, capital always is looking for ways to escape such risks. There are various ways to gain some protection against such threats, including the pursuit of monopoly power or protection by the state. However, shifting ownership of capital to financial capital [that is, to indirect ownership of capital] is the best way to insulate against the inherent risks of the capitalist marketplace (ibid.).

He further argues that the same risk affects also bank capital that traditionally finances productive activities, and the inherent financialization tendency will work itself out unless it is not held in check by the regulatory framework as in the postwar era. Thus he concludes that not only neoliberal deregulation drive gave rise to the rebirth of financialization but also the latter itself put pressure on the system to obtain a suitable (i.e., deregulated) framework to operate in. ${ }^{25}$

\footnotetext{
${ }^{24}$ Value becomes what Harvey (2006) calls anti-value. It ceases to be a part of capital in motion.

${ }^{25}$ Orhangazi (2008), on the contrary, argues that the non-financial corporation will invest in financial instead of real assets when a) "profit opportunities in financial markets are better than those in product markets" and if external funds are increasingly costly to acquire or riskier than internal funds to be preferred, and b) the short-termism dominates the corporation management logic so that rapid returns in financial markets becomes more preferable to medium- and long-term returns in product markets (871). His model includes financial income (the sum of interest income and equity in net earnings) to capture the effect of financial profits on real investment. However, as he states, his data source does not provide a comprehensive rate of financial profits datum (including capital gains and dividends received) for each firm. Thus his model does not, in fact, test the very hypothesis he wants to test. The hypothesis stated the way a) aforementioned above. What he tests what happens to real investment in the presence of financial income/profits. The estimation, by construction, cannot take care of the discrepancy between the profit rate in the product markets and the profit rate in the financial markets. Thus it is possible that his estimation suffers from the specification bias.
} 
The empirical accounts reviewed so far in the present work suggest that the financialization process has incorporated way more than switching from the direct ownership of productive capital to financial capital. Still, Kotz's argument might have an explanatory power to the extent that the switch has become a part of the overall and encompassing financialization process. Nonetheless it must be noted that the devaluation risk of capital is a real danger not only for fixed capital. It threatens the financial (i.e., mobile and relatively easily disposable) assets as well especially if the functioning of the financial capital circuits is founded more and more on the unstable foundations. As a matter of fact, the neoliberal growth processes in the US economy during the last decades are of such a nature, and the consequent instability (recurring asset bubbles and busts for instance (Kotz 2009)) might have worked as a countertendency to the financialization tendency. The evidence suggests that the latter has dominated the last decades. On the other hand, the countertendency can become more pronounced in shaping the investment strategies of productive capital after the 2008 crash even in the absence of a full-fledged regulatory restriction. Indeed, one of the biggest corporations in the US and world economy, General Electric (G.E.), decided to shed its GE Capital division that has dealt with financial operations within last three decades. Around only 50 percent of the company's profits have come from its industrial operations in early 2000s, and the significant involvement in financial markets brought huge loses after the Lehman Brothers collapse and forced the company to borrow debt to fulfill its daily operations (Merced and Sorkin 2015; Cox 2015). Since the 2008 crash the company has been divesting from financial activities: in 2014 it sold its consumer credit arm, and in 2015 it sold its commercial real assets (ibid.). Compared to 2008 in which GE Capital revenues 
Fall 2016

amounted to 42 percent of the GE's overall revenues, it was only 28 percent in 2014 . In the meantime G.E. buys businesses in its own productive field, and "... in three years [from 2015 on], G.E. expects to drive 90 percent of its earnings from industrial operations compared to 58 percent today. That's is a G.E. more like the one that Reg Jones pass on to Mr. Welch in 1981" (ibid.; emphasis added). ${ }^{26}$

\section{References}

Aglietta, Michel. 1979. A Theory of Capitalist Regulation: The US Experience.

Aglietta, Michel, and Régis Breton. 2001. "Financial Systems, Corporate Control and Capital Accumulation." Economy and Society 30 (4): 433-66.

Arrighi, Giovanni. 2010. The Long Twentieth Century: Money, Power and the Origins of Our Times. Second. London : New York, NY: Verso.

Baran, Paul A., and Paul M. Sweezy. 1966. Monopoly Capital: An Essay on the American Economic and Social Order. First. New York: Monthly Review Press.

Bowles, Samuel, David M Gordon, and Thomas E Weisskopf. 1990. After the Waste Land: A Democratic Economics for the Year 2000. Armonk, N.Y.: M.E. Sharpe, Inc.

Boyer, Robert. 1987. "Technical Change and The Theory of 'Regulation."” CEPREMAP.

- 2000. "Is a Finance-Led Growth Regime a Viable Alternative to Fordism? A Preliminary Analysis." Economy and Society 29 (1): 111-45.

Cox, Rob. 2015. "G.E. Is Finally Exorcising Financial Demons From Jack Welch Era." The New York Times, April 10. http://www.nytimes.com/2015/04/11/business/dealbook/ge-is-finally-exorcisingfinancial-demons-from-jack-welch-era.html.

Duménil, Gérard, and Dominique Levy. 2004. Capital Resurgent: Roots of the Neoliberal Revolution. Cambridge: Harvard University Press.

Epstein, Gerald. 2015. "Financialization: There's Something Happening Here.” Political Economy Research Institute.

Foster, John Bellamy. 2007. "The Financialization of Capitalism." Monthly Review, April.

. 2010. "The Age of Monopoly-Finance Capital.” Monthly Review 61 (9): 1-13.

Foster, John Bellamy, and Fred Magdoff. 2008. "Financial Implosion and Stagnation: Back to the Real Economy." Monthly Review 60 (7): 1-29.

Freeman, Joshua. 2016. "If You Can Make It Here." Accessed March 8. https://www.jacobinmag.com/2014/10/if-you-can-make-it-here/.

\footnotetext{
${ }^{26}$ Reginald H. Jones and Jack Welch were the previous CEOs of the G.E. before the current one, Jeffrey R. Immelt, under the management of who the company decided to turn its face more to its traditional productive business.
} 
Gordon, David M., Richard Edwards, and Michael Reich. 1994. "Long Swings and Stages of Capitalism." In Social Structures of Accumulation: The Political Economy of Growth and Crisis, edited by David M. Kotz, Terrence McDonough, and Michael Reich, 11-28. Cambridge University Press.

Harvey, David. 1989. The Urban Experience. Baltimore: Johns Hopkins University Press.

1990. The Condition of Postmodernity: An Enquiry into the Origins of Cultural Change. Oxford [England]; Cambridge, Mass., USA: Blackwell.

- 2006. The Limits to Capital. Second. London; New York: Verso. . 2007. "Neoliberalism and the City." Studies in Social Justice 1 (1): 2-13.

Jessop, Bob. 1990. "Regulation Theories in Retrospect and Prospect." Economy and Society 19 (2): 153-216.

. 2013. "Finance-Dominated Accumulation and the Limits to Institutional and Spatio-Temporal Fixes in Capitalism." In Fragile Stabilität - stabile Fragilität, edited by Stephan A. Jansen, Eckhard Schröter, and Nico Stehr. Springer-Verlag.

Kotz, David M. 2009. "The Financial and Economic Crisis of 2008: A Systemic Crisis of Neoliberal Capitalism." Review of Radical Political Economics 41 (3): 305-17.

. 2011. "Financialization and Neoliberalism." In Relations of Global Power: Neoliberal Order and Disorder, edited by Stephen McBride and Gary Teeple. Toronto: University of Toronto Press.

- 2015. The Rise and Fall of Neoliberal Capitalism. 1st edition. Cambridge, Massachusetts: Harvard University Press.

Kotz, David M., and Martin Wolfson. 2010. "A Reconceptualization of SSA Theory." In Contemporary Capitalism and Its Crises: Social Structure of Accumulation Theory for the 21st Century, edited by David M. Kotz, Terrence McDonough, and Michael Reich, First Edition, 72-90. Cambridge; New York: Cambridge University Press.

Krippner, Greta R. 2005. "The Financialization of the American Economy." SocioEconomic Review 3 (2): 173-208.

- 2011. Capitalizing on Crisis: The Political Origins of the Rise of Finance. Cambridge, Mass.: Harvard University Press.

Lapavitsas, Costas. 2011. “Theorizing Financialization.” Work, Employment \& Society 25 (4): 611-26.

- 2013. Profiting Without Producing: How Finance Exploits Us All. London; New York: Verso.

Lazonick, William. 2014. "Profits Without Prosperity." Harvard Business Review 92 (9): 46-55.

Lazonick, William, and Mary O'Sullivan. 2000. "Maximizing Shareholder Value: A New Ideology for Corporate Governance." Economy and Society 29 (1): 13-35.

Lin, Ken-Hou. 2016. "The Rise of Finance and Firm Employment Dynamics." Organization Science 27 (4): 972-88.

Lipietz, Alain. 1987. Mirages and miracles: the crisis in global Fordism. London: Verso.

- 1993. "From Althusserianism to 'Regulation Theory."' In The Althusserian Legacy, edited by E. Ann Kaplan and Michael Sprinker, 1st edition, 99-138. London; New York: Verso. 
Lipietz, Alain, and Michel Vale. 1988. "Accumulation, Crises, and Ways Out: Some Methodological Reflections on the Concept of "Regulation." International Journal of Political Economy 18 (2): 10-43.

Merced, Michael J. De La, and Andrew Ross Sorkin. 2015. "G.E. to Retreat From Finance in Post-Crisis Reorganization." The New York Times, April 10. http://www.nytimes.com/2015/04/11/business/dealbook/general-electric-to-sellbulk-of-its-finance-unit.html.

Orhangazi, Özgür. 2008. "Financialisation and Capital Accumulation in the NonFinancial Corporate Sector: A Theoretical and Empirical Investigation on the US Economy: 1973-2003." Cambridge Journal of Economics 32 (6): 863-86.

Philips-Fein, Kim. 2016. "The Legacy of the 1970s Fiscal Crisis." The Nation. Accessed March 8. http://www.thenation.com/article/legacy-1970s-fiscal-crisis/.

Sweezy, Paul M. 1982. "Why Stagnation?” Monthly Review 34 (June): 1-10.

Sweezy, Paul M. 1994. "The Triumph of Financial Capital." Monthly Review 46 (2): 1-7.

Tabb, William K. 1982. The Long Default: New York City and the Urban Fiscal Crisis. First Printing edition. New York: Monthly Review Press.

Wolfson, Martin H. 1994. "The Financial System and the Social Structure of Accumulation." In Social Structures of Accumulation: The Political Economy of Growth and Crisis, edited by David M Kotz, Terrence McDonough, and Michael Reich. Cambridge; New York: Cambridge University Press. 